\title{
The antioxidant activity, total phenolics and total flavonoids content of Bryonia dioica Jacq.
}

\author{
Mohammad Bagher Gholivand*, \\ Marzieh Piryaei \\ Department of Chemistry, \\ Faculty of Chemistry, \\ Razi University, \\ Kermanshah, Iran
}

\begin{abstract}
Bryonia dioica Jacq. is used as a medicinal plant in traditional medicine in the west of Iran. In this study, we investigated antioxidant activities, total phenols and flavonoid of several extracts (polar and nonpolar) obtained from B. dioica Jacq. flowers, leaves and stems for two stages of growth (flowering and pre-flowering). Several complementary assays, radical scavenging capacity, determination of total flavonoids and reducing power were used to screen the antioxidant properties of extracts. Large differences in the composition of phenolic compounds were detected among flower, leaf, and stem in different stages of growth. In the light of the data obtained, $B$. dioica Jacq. flowers represent an important source of phytochemicals with potent antioxidant capacity.
\end{abstract}

Key words: Bryonia dioica Jacq., antioxidant activity, stages of growth, DPPH

\section{INTRODUCTION}

Antioxidants are capable of scavenging free radicals, which can oxidize major biological macromolecules (DNA, protein, and lipid) in cells and tissues. If the oxidative damage is beyond the capacity of the natural repair mechanisms of the cells, it may trigger several human chronic diseases, such as cancer (Franco et al., 2008). The concept that consumption of antioxidant rich foods may prevent cancer or improve treatment has been supported by some studies. Results of these studies indicate that vitamins and certain phytochemical antioxidants including flavo-

\footnotetext{
* Corresponding author. E-mail: mbgholivand@yahoo.com
}

noids (flavones, flavonols, flavanones, catechins, anthocyanidins) and carotenoids are effective against the proliferation of human colorectal, breast and stomach cancer cells (Faria et al., 2006; Graf et al., 2005; Sexton et al., 2006; Singh et al., 2003; Wang et al., 2011). Antioxidants as potentially influencing human diseases may be sought directly or indirectly. Indeed selection by healers may integrate both ecological and human physiological insights. Considering that many of the factors associated with antioxidant accumulation are related to growing conditions, analysis of medicinal species in relation to antioxidant activity and habitat factors could offer better understanding of traditional gathering practices and provide guides to the likely location of species high in antioxi- 
dant activity. Plant species' life form influences what part and quantity of the species is available seasonally as well as where phytochemicals, such as antioxidants, may be stored. Different parts of a plant derive different benefits from accumulating phenolics or other types of antioxidant phytochemicals. Such compounds are important in pollinator recognition patterns on petals, as light or UV protectants, as feeding deterrents in leaves and bark and as allelopathic compounds in leaves, roots and other tissues. The growth conditions of medicinal plants could affect the antioxidant properties of herbal remedy through associated environmental factors such as UV stress, waterlogged conditions, prevalence of insect and foraging animals and the amount of plant competition (McCune et al., 2007). In the present study, the total phenolics, total flavonoids, and antioxidant activity of $B$. dioica Jacq. using an extended in vitro method in the different stages of growth were investigated. For this reason, several complementary test systems, namely $\beta$-carotene / linoleic acid assay, free radical scavenging activity, reducing power and ferrous ion chelating ability were used.

\section{MATERIALS AND METHODS}

\section{Plant material}

The aerial parts of $B$. dioica Jacq. (stems, leaves and flowers) in different stages (before flowering and flowering) were gathered in spring and summer 2011 in the west of Iran. Stems, leaves and flowers were dried in the shade (at room temperature) and were stored in the refrigerator at $4{ }^{\circ} \mathrm{C}$.

\section{Chemicals}

Linoleic acid, 2, 6-di-tert-butyl-4-methylphenol (butylated hydroxytoluene, BHT), 2, 2-diphenyl1-picrylhydrazyl (DPPH, 95\%), gallic acid and $\beta$-carotene were procured from Sigma-Aldrich Chemie (Steinheim, Germany). Analytical grade methanol, and HPLC grade chloroform, standard Folin-Ciocalteu's phenol reagent, anhydrous sodium sulphate, ferric chloride, sodium carbonate, potassium ferricyanide, phosphate buffer solution (PBS), and Tween 40 were obtained from Merck (Darmstadt, Germany).

\section{Preparation of the methanol extract}

Known amounts of dried leaf (40 g), stem (32 g) and flower $(20 \mathrm{~g})$ of $B$. dioica Jacq. in different stages of growth (before and during flowering) were extracted in methanol using Soxhlet apparatus at $60^{\circ} \mathrm{C}$ for $21 \mathrm{~h}$. The extract was filtered and concentrated under vacuum at $40{ }^{\circ} \mathrm{C}$ by using a rotary evaporator (Heidolph, Laborota 4000, Schwabach, Germany), yielding (5.67\%, $7.45 \%),(7.31 \%, 7.06 \%)$ and $(4.6 \%)$ of waxy materials for both stages (before and during flowering) for leaf, stem and flower, respectively. These extracts were suspended in water and extracted with chloroform $(4 \times 100 \mathrm{ml})$ to obtain polar and nonpolar subfractions. The percent of the extracted materials after removing the solvent is shown in Table 1 . The extracts were stored in darkness at $4{ }^{\circ} \mathrm{C}$ until used within a maximum period of one week.

\section{Antioxidant properties}

\section{1, 1-Diphenyl-2-picrylhydrazyl radical (DPPH)} scavenging activity

The free radical-scavenging activities of extract were measured by using 2, 2-diphenyl-1-picrylhydrazyl (DPPH) as described by Sharififar et al. (2007) with some modification. $3 \mathrm{ml}$ of various concentrations of the extract were added to $1 \mathrm{ml}$ of a $0.5 \mathrm{mM}$ methanol solution of DPPH. The mixture was strongly shaken and left to stand at room temperature for $60 \mathrm{~min}$ in the dark. Then the absorbance was measured at $515 \mathrm{~nm}$ against a blank. Inhibition of free radical, DPPH, in percent (I\%) was calculated according to the formula:

Table 1. The percent of extracted materials with polar (water) and nonpolar (chloroform) fractions

\begin{tabular}{|c|c|c|c|c|}
\hline \multirow{2}{*}{ Stage } & \multirow{2}{*}{ Fraction } & \multicolumn{3}{|c|}{ Percent of extracted (\%) } \\
\hline & & stem & leaf & flower \\
\hline \multirow{2}{*}{ Before flowering } & Polar subfraction & 3.35 & 4.87 & - \\
\hline & Nonpolar subfraction & 2.1 & 2.8 & - \\
\hline \multirow{2}{*}{ During flowering } & Polar subfraction & 4.3 & 4.46 & 2.95 \\
\hline & Nonpolar subfraction & 2.6 & 2.4 & 1.9 \\
\hline
\end{tabular}




$$
\mathrm{I} \%=\left(\left(\mathrm{A}_{\mathrm{b}}-\mathrm{A}_{\mathrm{s}}\right) / \mathrm{A}_{\mathrm{b}}\right) \times 100
$$

where $A_{b}$ is the absorbance of the control reaction (containing all reagents except the test compound), and $\mathrm{A}_{\mathrm{s}}$ is the absorbance of the test compound. The sample concentration providing 50\% inhibition $\left(\mathrm{IC}_{50}\right.$ ) was calculated from the graph of inhibition percentage against sample concentration. Tests were carried out in triplicate. Ascorbic acid (AA) was used as a positive control.

\section{$\beta$-Carotene linoleic acid assay}

The antioxidant activity was evaluated according to the method described by Miller (1971). Briefly, $1.5 \mathrm{~mL}$ of $\beta$-carotene solution $(1 \mathrm{mg} / \mathrm{mL}$ in chloroform), $3 \mathrm{~mL}$ of linoleic acid solution $(10 \mathrm{mg} / \mathrm{mL}$ in chloroform), and $1.0 \mathrm{~mL}$ of Tween 40 solution (300 $\mathrm{mg} / \mathrm{mL}$ in chloroform) were pipetted into a $250 \mathrm{~mL}$ flask. The chloroform was removed by rotary vacuum evaporator, and $150 \mathrm{~mL}$ deionized water was added to the residue and the mixture was shaken to form an emulsion. $350 \mu \mathrm{L}$ of test sample in methanol $(2 \mathrm{mg} / \mathrm{mL})$ was mixed with $2.5 \mathrm{~mL}$ of this reagent, and the emulsion system was incubated for up to $24 \mathrm{~h}$ at room temperature. The same procedure was repeated with the synthetic antioxidant, BHT as a positive control, and a blank containing only $350 \mu \mathrm{L}$ of methanol. After the incubation period, the absorbance of the mixtures was measured at $490 \mathrm{~nm}$. Antioxidative capacities of the extract were compared with those of BHT and blank.

\section{Reducing power}

The reducing power of extract was determined according to the method of Jahanban Sfahlan et al. (2009). Different concentrations of methanolic extract (polar and nonpolar) of plant in methanol $(1.0 \mathrm{~mL})$ were mixed with $2.5 \mathrm{~mL}$ of phosphate buffer $(200 \mathrm{mM}, \mathrm{pH} 6.6)$ and $2.5 \mathrm{~mL}$ of $1 \%$ potassium ferricyanide. The mixture was incubated at $50{ }^{\circ} \mathrm{C}$ for $20 \mathrm{~min}$. A portion $(2.5 \mathrm{~mL})$ of trichloroacetic acid $(10 \%)$ was added to the mixture to stop the reaction, which was then centrifuged at $3000 \mathrm{~g}$ for $10 \mathrm{~min}$. The upper layer of solution $(2.5 \mathrm{~mL})$ was mixed with distilled water $(2.5 \mathrm{~mL})$ and $\mathrm{FeCl}_{3}(0.5 \mathrm{~mL}, 0.1 \%)$, and the absorbance was measured at $700 \mathrm{~nm}$ : higher absorbance indicates higher reducing power. Ascorbic acid was used as a positive control.

\section{Determination of total phenolic contents}

Total phenolic contents of the extract and the oil were determined using the Folin-Ciocalteu's reagent according to the method of Singleton et al. (1965) using gallic acid as standard, with some modifications. The extract solution $(0.1 \mathrm{~mL})$ containing $1000 \mu \mathrm{g}$ of the extract was mixed with $46 \mathrm{~mL}$ of distilled water in a volumetric flask, $1 \mathrm{~mL}$ Folin-Ciocalteu's reagent was added, and the flask was thoroughly shaken. The mixture was allowed to react for $3 \mathrm{~min}$ and $3 \mathrm{~mL}$ aqueous solution of $2 \% \mathrm{Na}_{2} \mathrm{CO}_{3}$ was added. At the end of incubation of $2 \mathrm{~h}$ at room temperature, absorbance of each mixture was measured at $760 \mathrm{~nm}$. The same procedure was also applied to the standard solutions of gallic acid, and a standard curve was obtained. Total phenol contents were expressed as $\mu \mathrm{g}$ gallic acid equivalents per mg of the extract. All tests were carried out in triplicate, and gallic acid equivalent values were reported as $\mathrm{X} \pm \mathrm{SD}$ of triplicates.

\section{Determination of total flavonoid}

Total flavonoid content was measured according to a colorimetric assay (Zhishen et al., 1999). $1-\mathrm{mL}$ aliquot of standard solution of quercetin at different concentrations $(0.001-2 \mathrm{mg} / \mathrm{mL}$, external calibration with $\mathrm{n}=8$ concentrations) or the methanolic extract was added to 10 - $\mathrm{mL}$ volumetric flasks containing $4 \mathrm{~mL}$ water. At the onset of the experiment, $0.3 \mathrm{~mL}$ of $5 \% \mathrm{NaNO}_{2}$ and after $5 \mathrm{~min} 0.3 \mathrm{~mL}$ of $10 \% \mathrm{AlCl}_{3}$ were added to the flask. At $6 \mathrm{~min}, 2 \mathrm{~mL}$ of $1 \mathrm{M} \mathrm{NaOH}$ was added to the mixture and the solution was diluted to a final volume of $10 \mathrm{~mL}$ with water and mixed thoroughly. Absorbance of the mixture was determined at $510 \mathrm{~nm}$ versus the prepared blanks. Total flavonoid content in B. dioica Jacq was expressed as $\mu \mathrm{g}$ quercetin equivalents (CE) per $100 \mathrm{mg}$ fresh weight (Bouayed et al., 2011).

\section{RESULTS AND DISCUSSION}

The free radical-scavenging abilities of the polar and nonpolar fractions (water, chloroform) of methanolic extract of $B$. dioica Jacq. against DPPH were tested, and the results are presented in Table 2 for two stages of growth (before and during flowering stages) for stem, leaf and flower. The effect of antioxidant on DPPH radical 
Table 2. DPPH radical-scavenging activities of $B$. dioica Jacq for flower, leaf and stem in before and during flowering

\begin{tabular}{|c|c|c|c|c|}
\hline \multirow{2}{*}{ Stage } & \multirow{2}{*}{ Fraction } & \multicolumn{3}{|c|}{$\mathrm{IC}_{50}(\mu \mathrm{g} / \mathrm{mL})$} \\
\hline & & stem & leaf & flower \\
\hline \multirow[b]{2}{*}{ Before flowering } & Polar subfraction & $425.31 \pm 15.52$ & $238.19 \pm 8.53$ & - \\
\hline & $\begin{array}{c}\text { Nonpolar } \\
\text { subfraction }\end{array}$ & $342.73 \pm 13.86$ & $112.46 \pm 8.64$ & - \\
\hline \multirow[b]{2}{*}{ Flowering } & Polar subfraction & $321.41 \pm 11.43$ & $79.54 \pm 6.05$ & $23.17 \pm 2.24$ \\
\hline & $\begin{array}{l}\text { Nonpolar } \\
\text { subfraction }\end{array}$ & $285.67 \pm 9.38$ & $48.32 \pm 3.86$ & $31.25 \pm 3.38$ \\
\hline
\end{tabular}

scavenging was thought to be due to their hydrogen donating ability or radical-scavenging activity. When a solution of DPPH is mixed with that of a substance that can donate a hydrogen atom, then this gives rise to the reduced form 1 , 1-diphenyl-2-picryl hydrazine (non-radical) with the loss of violet color (Molyneux, 2004). DPPH scavenging activity is usually presented by $\mathrm{IC}_{50}$ value, defined as the concentration of the antioxidant needed to scavenge $50 \%$ of DPPH present in the test solution. Therefore, polar and nonpolar concentrations providing $50 \%$ inhibition $\left(\mathrm{IC}_{50}\right)$ were presented in Table 2 . Lower $\mathrm{IC}_{50}$ value reflects A better DPPH radical-scavenging activity. The polar subfraction of flower provided the highest radical-scavenging activity with the lowest IC ${ }_{50}$ value of $23.17 \pm 4.24 \mu \mathrm{g} / \mathrm{ml}$. The $\mathrm{IC}_{50}$ of the nonpolar subfraction of flower, polar and nonpolar subfraction of leaf and stem for both stages (before and during flowering) were $31.25 \pm 5.38$, $238.19 \pm 9.53,112.46 \pm 10.64,79.54 \pm 8.05$, $48.22 \pm 5.86,425.31 \pm 15.52,342.73 \pm 14.43$, $321.41 \pm 14.43,285.67 \pm 11.38 \mu \mathrm{g} / \mathrm{ml}$, respectively. DPPH scavenging activity of extracts increased in the order of ascorbic acid $>$ BHT $>$ polar subfraction of flower $>$ nonpolar subfraction of flower $>$ nonpolar subfraction in flowering stage of leaf $>$ polar subfraction in flowering stage of leaf $>$ nonpolar subfraction in before flowering stage of leaf $>$ polar subfraction in before flowering stage of leaf $>$ nonpolar subfraction in flowering stage of stem $>$ polar subfraction in flowering stage of stem $>$ nonpolar subfraction in before flowering stage of stem $>$ polar subfraction in before flowering stage of stem. Ascorbic acid and BHT were used as standards. The antioxidant activities of the plant extract were also evaluated by the spectrophotometric $\beta$-carotene bleaching test. In a $\beta$-carotene/ linoleic acid model system, $\beta$-carotene undergoes rapid discoloration in the absence of an antioxidant. $\beta$-Carotene bleaching method is based on the loss of the yellow color of $\beta$-carotene due to its reaction with radicals formed by linoleic acid oxidation in an emulsion. The rate of $\beta$-carotene bleaching can be slowed down in the presence of antioxidants (Kulisic et al., 2004). The relative antioxidative activities (RAAs) of the extracts were calculated from the equation $\mathrm{RAA}=\mathrm{A}_{\text {sample }} / \mathrm{A}_{\mathrm{BHT}}$, where $\mathrm{A}_{\mathrm{BHT}}$ is the absorbance of the control (BHT) and $\mathrm{A}_{\text {sample }}$ is the absorbance of the extract. The calculated RAAs of the extract are given in Table 3 for polar and nonpolar subfraction in flowering and before flowering stages. The inhibition values of linoleic acid oxidation were estimated at $98.35 \pm 8.7 \%, 91.54 \pm 6.51 \%$, $76.08 \pm 7.34 \%, 83.62 \pm 4.91 \%, 47.92 \pm 2.36 \%$,

Table 3. The relative antioxidative activities (RAAs) of $B$. dioica Jacq. for flower, leaf and stem before and during flowering

\begin{tabular}{c|c|c|c|c}
\hline \multirow{2}{*}{ Stage } & \multirow{2}{*}{ Fraction } & \multicolumn{2}{|c}{$\beta$-carotene bleaching (RAA) (\%) } \\
\cline { 2 - 5 } Before flowering & stem & leaf & flower \\
\cline { 2 - 5 } & Polar subfraction & $19.68 \pm 1.16$ & $47.92 \pm 2.36$ & - \\
\hline \multirow{2}{*}{ Flowering } & $\begin{array}{c}\text { Nonpolar } \\
\text { subfraction }\end{array}$ & $23.42 \pm 2.71$ & $68.49 \pm 3.57$ & - \\
\cline { 2 - 5 } & Polar subfraction & $28.75 \pm 2.65$ & $76.08 \pm 5.34$ & $98.35 \pm 6.38$ \\
\cline { 2 - 5 } & $\begin{array}{c}\text { Nonpolar } \\
\text { subfraction }\end{array}$ & $31.27 \pm 2.88$ & $83.62 \pm 5.91$ & $91.54 \pm 5.51$ \\
\hline
\end{tabular}


$68.49 \pm 4.57 \%, 28.75 \pm 3.65 \%, 31.27 \pm 2.58 \%$, $19.68 \pm 2.16 \%, 23.42 \pm 3.71 \%$ in the presence of the polar and nonpolar subfraction of flower, leaf, and stem in flowering and pre-flowering of methanolic extract, respectively. A relationship between the DPPH scavenging ability and $\beta$-carotene bleaching extent was found. Different studies have indicated that the electron donation capacity reflects the reducing power of bioactive compounds which is related to antioxidant activity. Antioxidants can be explained as reducers, and inactivation of oxidants by reducers can be described as redox reaction in which one reaction species is reduced at the expense of the oxidation of the other. $\mathrm{Fe}^{3+}$ reduction is often used as an indicator of electron donating activity, which is an important mechanism of phenolic antioxidant action (Yildirim et al., 2001). In the reducing power assay, the presence of antioxidants in the sample would result in the reducing of $\mathrm{Fe}^{3+}-\mathrm{Fe}^{2+}$ by donating an electron. Amount of $\mathrm{Fe}^{2+}$ complex can be then monitored by measuring the formation of Perl's Prussian blue $\left(\mathrm{Fe}^{4}\left[\mathrm{Fe}(\mathrm{CN})_{6}\right]^{3}\right)$ at $700 \mathrm{~nm}$. Increasing absorbance at $700 \mathrm{~nm}$ indicates an increase in reductive ability. Figures 1 and 2 show the reducing power of the methanolic (polar and nonpolar) extract of B. dioica Jacq. as a function of their concentrations. The amounts of total phenolics in the extract for different stages were determined spectrometrically according to

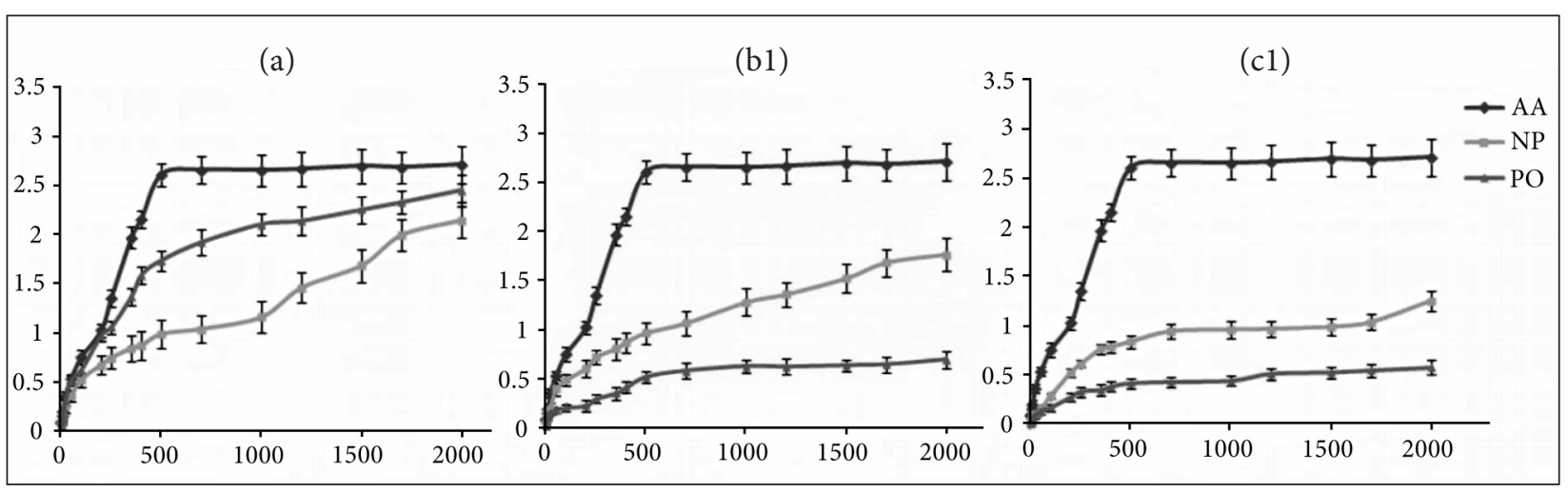

Fig. 1. Reducing power of different concentrations of methanol extract polar and nonpolar subfraction of flowers (a), leaves (b1) and stems (c1) compared to ascorbic acid. Polar (PO) and nonpolar (NO) subfraction extract; AA, ascorbic acid

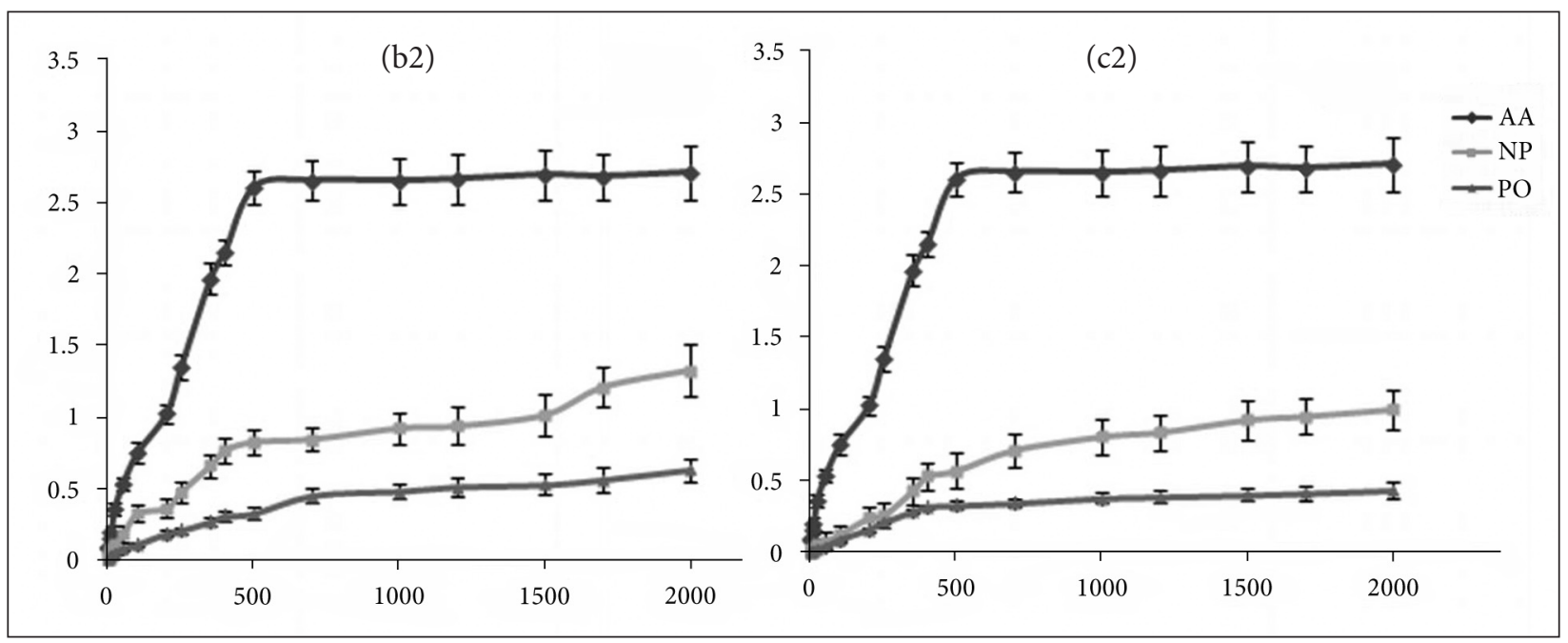

Fig. 2. Reducing power of different concentrations of methanol extract polar and nonpolar subfraction in the before flowering stage of leaves (b2) and stems (c2) compared to ascorbic acid. Polar (PO) and nonpolar (NO) subfraction extract; AA, ascorbic acid 
Table 4. Effect of different extraction methods on total phenolic content of B. dioica Jacq. for flower, leaf and stem before and during flowering

\begin{tabular}{|c|c|c|c|c|}
\hline \multirow{2}{*}{ Stage } & \multirow{2}{*}{ Fraction } & \multicolumn{3}{|c|}{ Total phenolics $(\mu \mathrm{g} / \mathrm{mg})$} \\
\hline & & stem & leaf & flower \\
\hline \multirow[b]{2}{*}{ Before flowering } & Polar subfraction & $35.18 \pm 2.29$ & $151.92 \pm 7.54$ & - \\
\hline & $\begin{array}{c}\text { Nonpolar } \\
\text { subfraction }\end{array}$ & $42.47 \pm 3.14$ & $175.43 \pm 9.47$ & - \\
\hline \multirow[b]{2}{*}{ Flowering } & Polar subfraction & $47.66 \pm 3.21$ & $186.34 \pm 9.62$ & $226.57 \pm 10.62$ \\
\hline & $\begin{array}{l}\text { Nonpolar } \\
\text { subfraction }\end{array}$ & $62.05 \pm 3.39$ & $203.21 \pm 6.38$ & $241.32 \pm 11.38$ \\
\hline
\end{tabular}

the Folin-Ciocalteu procedure and calculated as gallic acid equivalents. Gallic acid is a watersoluble polyhydroxyl phenolic compound that can be found in various natural plants (Sun et al., 2002). The standard curve equation was y (absorbance $)=0.0003 \times$ gallic acid $(\mu \mathrm{g})+0.00534$. The absorbance value was inserted in the above equation and the total amount of phenolic compound was calculated. The amounts of total phenols found in the plant methanolic extract are shown in Table 4. The standard curve equation for determination of flavonoids with quercetin is $\mathrm{y}(\mathrm{ab}-$ sorbance $)=0.004 \times$ quercetin $(\mu \mathrm{g})+0.0483$. The amounts of total flavonoids found in plant methanolic extract for flowers of $B$. dioica Jacq. were $128.31 \pm 7.34 \mu \mathrm{g}, 93.26 \pm 6.82 \mu \mathrm{g}, 48.34 \pm 4.08 \mu \mathrm{g}$ for leaf and $32.14 \pm 2.45$ and $19.74 \pm 1.39$ for stem in before and during flowering stages, respectively. The results indicated that the flower of polar and nonpolar subfraction $(226.57 \pm 10.62$, $241.32 \pm 11.38$ ) have highest total phenolic compounds (Table 4 ). In addition, according to these results, there is a relationship between total phenol contents and antioxidant activity. Phenolic compounds, biologically active components, are the main agents that can donate hydrogen to free radicals and thus break the chain reaction of lipid oxidation at the first initiation step. This high potential of phenolic compounds to scavenge radicals may be explained by their phenolic hydroxyl groups (Oke et al., 2009).

\section{CONCLUSIONS}

According to the results of this study, the methanolic extracts of $B$. dioica Jacq. may be suggested as a new potential source of natural antioxidant. The methanolic extract in different stages of growth was found to be effective antioxidants in different in vitro assays, including $\beta$-carotene bleaching, $\mathrm{DPPH}$ radical scavenging and reducing power which can be proposed as a natural additive in food and pharmaceutical industries. The polar extraction of flower of $B$. dioica Jacq. had a higher total phenolic content as well as antioxidant activity compared to that of other subfractions of flower, leaf and stem in different stages. There was a good correlation between total phenol content and antioxidant capacity of the extracts.

Received 4 July 2012 Accepted 11 October 2012

\section{References}

1. Bouayed J, Hoffmann L, Bohn T. Total phenolics, flavonoids, anthocyanins and antioxidant activity following simulated gastro-intestinal digestion and dialysis of apple varieties: Bioaccessibility and potential uptake. Food Chem 2011; 128: 14-21.

2. Faria A, Calhau C, de Freitas V, Mateus N. Procyanidins as antioxidants and tumor cell growth modulators. J Agric Food Chem 2006; 54: 2392-7.

3. Franco R, Schoneveld O, Georgakilas AG, Panayiotidis MI. Oxidative stress, DNA methylation and carcinogenesis. Cancer Letters 2008; 266: 6-11.

4. Graf BA, Milbury PE, Blumberg JB. Flavonols, flavones, flavanones, and human health: Epidemiological evidence. J Medicin Food 2005; 8: 281-90.

5. Jahanban Sfahlan A, Mahmoodzadeh A, Hasanzadeh A, Heidari R, Jamei R. Antioxidants and antiradicals in almond hull and shell (A. communis L.) as a function of genotype. Food Chem 2009; 115: 529-33. 
6. Kulisic T, Radonic A, Katalinic V, Milos M. Use of different methods for testing antioxidative activity of oregano essential oil. Food Chem 2004; 85: 633-40.

7. McCune LM, Johns T. Antioxidant activity relates to plant part, life form and growing condition in some diabetes remedies. J Ethnopharmacol 2007; 112: 461-9.

8. Miller HE. A simplified method for the evaluation of antioxidants. J Amer Oil Chemists' Soc 1971; 48: 91-7.

9. Molyneux P. The use of the stable free radical diphenylpicrylhydrazyl (DPPH) for estimating antioxidant activity. Songklanakarin J Sci Technol 2004; 26: 211-9.

10. Oke F, Aslim B, Ozturk S, Altundag S. Essential oil composition, antimicrobial and antioxidant activities of S. cuneifolia Ten. Food Chem 2009; 112: 874-9.

11. Sexton E, Themsche CV, Leblanc K, Parent S, Lemoine P, Asselin E. Resveratrol interferes with AKT activity and triggers apoptosis in human uterine cancer cells. Mol Cancer 2006; 5: 1-13.

12. Singh B, Bhat T, Singh B. Potential therapeutic applications of some antinutritional plant secondary metabolites. J Agr Food Chem 2003; 51: 5579-97.

13. Singleton VL, Rossi JA. Colorimetry of total phenolics with phosphomolybdic-phosphotungstic acid reagents. Amer J Enol Viticult 1965; 16: 144-58.

14. Sharififar F, Moshafi MH, Mansouri SH, Khodashenas $\mathrm{M}$, Khoshnoodi $\mathrm{M}$. In vitro evaluation of antibacterial and antioxidant activities of the essential oil and methanol extract of endemic Z. multiflora Boiss. Food Control 2007; 18: 800-5.

15. Sun J, Chu YF, Wu X, Liu RH. Antioxidant and antiproliferative activities of common fruits. J Agr Food Chem 2002; 50: 449-54.

16. Wang S, Meckling KA, Marcone MF, Kakuda Y, Tsao R. Can phytochemical antioxidant rich foods act as anti-cancer agents? Food Res Intern 2011; 46: 2545-54.

17. Yildirim A, Mavi A, Kara A. Determination of antioxidant and antimicrobial activities of $R$. crispus $\mathrm{L}$. extracts. J Agr Food Chem 2001; 49: 4083-9.

18. Zhishen J, Mengcheng T, Jianming W. The determination of flavonoid contents in mulberry and their scavenging effects on superoxide radicals. Food Chem 1999; 64: 555-9.
Mohammad Bagher Gholivand, Marzieh Piryaei

ANTIOKSIDANTŲ AKTYVUMAS FENOLIŲ IR FLAVONOIDŲ EKSTRAKTUOSE, IŠSKIRTUOSE IŠ BRYONIA DIOICA JACQ. ŽIEDŲ, LAPŲ IR STIEBŲ DVIEJOSE AUGIMO STADIJOSE

\section{Santrauka}

Tradicinè medicina vakarų Irane raudonuogę Bryonia dioica Jacq. naudoja kaip vaistini augalą. Šiame tyrime analizavome antioksidantų veiksmingumą fenolių ir flavonoidų ekstraktuose (poliariniame ir nepoliariniame), išskirtuose iš Bryonia dioica Jacq. žiedų, lapų ir stiebų dviejose augimo stadijose (žydejjimo ir prieš žydejjimą). Aptiktas bendras flavonoidų kiekis ir jo mažèjimas buvo pritaikytas antioksidantų savybèms ekstraktuose nustatyti. Lyginant fenolinius junginius buvo nustatyti dideli skirtumai tarp žiedų, lapų ir stiebų skirtingose augimo stadijose. Gauti duomenys rodo, kad Bryonia dioica Jacq. žiedai yra svarbus fitochemikalų šaltinis, pasižymintis stipriu antioksidantiniu poveikiu.

Raktažodžiai: Bryonia dioica Jacq., antioksidantų aktyvumas, augimo stadija, DPPH 